\title{
Extent of Heavy Metal Accumulation in Sewage Irrigated Soils and their Impact on Distribution of Earthworm Communities: Linking Chromium and Zinc Toxicity on Growth and Reproduction in Selected Earthworm Species
}

\author{
V LATHA and P MAHABOOB BASHA* \\ Department of Zoology, Bangalore University, Bangalore-560 056, India. \\ http://dx.doi.org/10.12944/CWE.11.1.34
}

(Received: February 08, 2016; Accepted: March 23, 2016)

\begin{abstract}
Soil ecosystem polluted by metals affect the structure of soil invertebrate population(s) and dynamics leading to altered distribution of species. This study focuses on earthworm distribution in sewage irrigated agricultural lands around Bangalore. The occurrence of reported species from the sampled areas is Eudrilus eugeniae, Lampito maurutii, Pontoscolex corethrurus, Polypheretima elongata, Perioynx excavates and Eisenia fetida. Laboratory studies conducted to evaluate feed ingestion rate and body mass changes in earthworms exposed to metal spiked soils revealed species specific pattern. Eudrilus eugeniae and Lampito maurutii showed a steep increase in body weight, while Pontoscolex corethrurus exhibited decreased trend upon $\mathrm{Zn}$ exposure. Contrarily a significant $(p<0.05)$ decline in body weight was evident in all the three species upon exposure to $\mathrm{Cr}$ spiked soils. The observed alterations in feeding and body mass index concomitantly influenced the reproductive parameters. Rate of hatchability and reproductive function found to be decreased in $\mathrm{Cr}$ spiked soils in all the three species studied. Contrarily, increased hatchability was observed in E.eugeniea and L.maurutii followed by a decrease rate in P.corethrurus upon exposure of $\mathrm{Zn}$ spiked soils. However, reproductive rate found to be increased in E.eugeniea and P.corethrurus with decreased trend in L.maurutii. Thus, use of sewage polluted water for irrigation purpose has led to increased soil metal concentration impacting earthworm physiology and distribution.
\end{abstract}

Keywords: Heavy metal toxicity, Earthworm prevalence,

Feeding and body mass changes, Reproductive parameters.

\section{INTRODUCTION}

Improper disposal of sewage effluents and irrigation practices with polluted waters has increased the concentration of metals in agricultural soils. This has led to increased concentration of metals in organic matter in soils which are fed by earthworms leading to bioaccumulation and biotransformation. In ecosystem, biota are generally exposed to low levels of toxic pollutants, among all, heavy metals are more toxic, as they biomagnifies through food chain ${ }^{1}$. Earthworms are sensitive biomarkers for evaluating soil toxicity as they are in contact with soil continuously by ingesting and burrowing in soil. They are important in terms of soil functionality ${ }^{2}$ and play a key role in terrestrial ecotoxicological risk assessment ${ }^{3}$. Organisms respond to change in climatic conditions like loss of moisture, temperature fluctuations and toxic chemicals induced by anthropogenic activities that are considered as stressors, and regulated by set of interactions between biotic and abiotic factors. Congregating above, Vrankel et al., ${ }^{4}$ suggested multi-factorial approaches which are more pragmatic in comparison with single toxicant assay using any single species. 
Several attempts have been made to understand the earthworm diversity and distribution in India. For instance, Julka et al., ${ }^{5}$ reported 590 species of earthworms from all over India, while earthworm diversity reported in different parts of India such as from north Indian states ${ }^{6}$; north eastern states ${ }^{7}$,Tamilnadu ${ }^{8}$ and few districts of Karnataka like Gulbarga ${ }^{9}$ and Bangalore ${ }^{10}$. In recent times no study has been undertaken to survey earthworm, keeping prevalence of high pollution rates in Bangalore district.

Thereby, this study aimed to study the prevalence of earthworms species in sewage irrigated agricultural lands adjoining to the industrial pockets of Bangalore. Subsequently, their feeding behaviour and body mass changes in laboratory conditions assessed upon exposure to sub lethal doses of selected heavy metals chromium $(\mathrm{Cr})$ and Zinc (Zn) for 7, 14, 21 and 28days.

\section{MATERIALS AND METHODS}

\section{Study site}

With its continuous expansion, human settlements and industries have taken over the agricultural fields by large amount in Bangalore $\left(12^{\circ} .58^{\prime} \mathrm{N}\right.$ and $\left.77^{\circ} .35^{\prime} \mathrm{E}, 921 \mathrm{MSL}\right)$. This has resulted in the shrinkage of land available for farming affecting soil fertility. The study sites were chosen along Vrishabavathi valley where lands are irrigated with sewage effluents and in Attibele industrial area where industries are located adjoining to agricultural fields. In all the selected villages minimum of five sub samples of top $10 \mathrm{~cm}$ of soil was sampled and hand sorted to remove root and litters to achieve randomness. The samples were stored in labelled polythene bags prior to analysis mixed up well and analysed in three replicates. Earthworms prevailing in each site was collected along with the soils in a plastic culture boxes with perforated lid and transported to the laboratory and acclimatised for further identification and use.

\section{Soil analysis}

Soil $\mathrm{pH}$ was measured using $\mathrm{pH}$ meter (Thermo-orion) and Electric conductivity (EC) is measured using EC meter and expressed as $\mathrm{mmhos} / \mathrm{cm}$.

\section{Organic carbon}

Organic carbon was determined by Walkley and Black ${ }^{11}$ method.1.0g of soil was weighed in $500 \mathrm{ml}$ conical flask, to this $10 \mathrm{ml}$ of $0.1667 \mathrm{M}$ $\mathrm{K}_{2} \mathrm{Cr}_{2} \mathrm{O}_{7}$ solution and $20 \mathrm{ml}$ concentrated $\mathrm{H}_{2} \mathrm{SO}_{4}$ containing $\mathrm{Ag}_{2} \mathrm{SO}_{4}$ was added and mixed thoroughly for $30 \mathrm{~min}$ to complete the reaction. The reaction mixture was further diluted by using $200 \mathrm{ml}$ of $\mathrm{H}_{2} \mathrm{O}$ and $10 \mathrm{ml}$ of phosphoric acid and $10 \mathrm{ml}$ of sodium fluoride solution. Diphenylamine was used as indicator. Titration was carried out with $0.5 \mathrm{M} \mathrm{FeSO} 4$ with brilliant blue colour as end point. Results are presented as percentage organic carbon $\times 1.3$, as the organic carbon recovery is found to be in the range of $77 \%$.

\section{Available Phosphorous}

Available phosphorous was determined by Olsen's et al. method ${ }^{12}$. Available phosphorous in soil is extracted in Olsen's $\mathrm{P}\left(0.5 \mathrm{M} \mathrm{NaHCO}{ }_{3}\right.$ solution at $\mathrm{pH}$ 8.5) extractant under neutral to alkaline soil conditions. $50 \mathrm{ml}$ of the bicarbonate extractant was added to $100 \mathrm{ml}$ conical soil sample and. The mixture was kept on mechanical shaker for $30 \mathrm{~min}$ and then filtered. The colour intensity was measured spectrophotometrically.

\section{Available Potassium}

Available potassium was determined by Merwin and Peach method ${ }^{13}$. It was estimated with the help of flame photometer. $25 \mathrm{ml}$ containing $5 \mathrm{~g}$ soil sample and stirred thoroughly for $5 \mathrm{~min}$ and resulting supernatant was filtered and amount of potassium was measured with flame photometer.

\section{Available micro-nutrients (AAS)}

Standard procedures were adopted to analyse elemental composition of soil using atomic absorption spectrophotometer (AAS) ${ }^{14}$ and results were expressed as $\mu \mathrm{g} / \mathrm{ml}$.

\section{Selection of species for laboratory studies}

Worms were carefully brought to the laboratory and allowed to stabilize for one month under laboratory conditions in plastic culture boxes containing soil and organic matter containing farmyard manure mixture (9:1) with 35 to $40 \%$ of moisture content and $\mathrm{pH}$ in the range of 6.8 to 7.0 . Earthworm species which were active with well- 
developed clitella viz., E.eugeniae, L. maurutii and $P$. corethrurus were chosen for further studies. They were carefully picked from the culture boxes $24 \mathrm{hrs}$ prior to use and placed on damp filter paper (in the dark at $28 \pm 2{ }^{\circ} \mathrm{C}$ ) in petridishes for removal of gut contents.

\section{Selection of metal concentrations and $\mathrm{LC}_{50}$ values}

Zinc $(\mathrm{Zn})$ is an essential trace element, readily available in soils, and basically required for the healthy functioning of biological systems. In soils zinc toxicity depends on soil characteristics and is found toxic when present at elevated level. Zinc concentrations in soils are of great importance in terms of soil health and toxicity ${ }^{15}$. As per available literature the concentration of $\mathrm{Zn}$ in sewage irrigated agricultural soils and few selected industrial pockets of Bangalore were in the range of $2-15 \mathrm{ppm}$. Furthermore, Schalscha et al. ${ }^{16}$ reported 228ppm of $\mathrm{Zn}$ in wastewater treated soils. The 14-day $\mathrm{LC}_{50}$ was conducted according to OECD guidelines and $50 \%$ mortality in $\mathrm{Zn}$ spiked soils were observed at 1067.64ppm ( $\left.R^{2}=0.8639\right), 1159.9 p p m\left(R^{2}=0.839\right)$ and 1164.3ppm $\left(R^{2}=0.7561\right)$ for E.eugeniae, $L$. maurutii and $P$. corethrurus respectively.

Likewise, biologically, trivalent $\mathrm{Cr}$ is an essential element for animals which is essential for glucose metabolism ${ }^{17}$, while hexavalent $\mathrm{Cr}$ shown to be toxic as a mutagenic, carcinogenic, and teratogenic agent ${ }^{18}$. Unlike other metals, $\mathrm{Cr}^{+6}$ have not received much attention from an ecotoxicological point of view ${ }^{19}$ thereby hexavalent form of chromium $\left(\mathrm{K}_{2} \mathrm{Cr}_{2} \mathrm{O}_{7}\right)$ used in this study. $\mathrm{Cr}$ occurs in nature in different concentrations in soil (10-50ppm), sea water $(0.1-117 \mathrm{ppb})$ and atmosphere $\left[5.0 \times 10^{-6}-1.2\right.$ $x 10^{-3} \mathrm{ugm}^{-3}$. As per the industries data available from Indian tanning industries, about 2000 to 32,000 tons of $\mathrm{Cr}$ escapes into the environment ${ }^{20}$. The concentration of total $\mathrm{Cr}$ reported in Bangalore soils were below the permissible limit (0.1-0.3ppm). In effluents the permissible limit of $\mathrm{Cr}$ is up to $2 \mathrm{ppm}$, as prescribed by central pollution control board, India. Likewise, 14day $\mathrm{LC}_{50}$ values of $\mathrm{Cr}(\mathrm{VI})$ were observed to be 22.35ppm ( $\left.R^{2}=0.8393\right), 16.57 p p m\left(R^{2}=0.9601\right)$ and $17.25 \mathrm{ppm}\left(\mathrm{R}^{2}=0.9601\right)$ for E.eugeniae, $L$. maurutii and $P$. corethrurus respectively derived by Finney's ${ }^{21}$ probit mortality. In view of the above ranges, a sub-lethal dose of 8ppm was used in the present study.

\section{Preparation of experimental beds}

Before experimentation, the experimental beds having air-dried soil and sun-dried, urine-free cow dung in the ratio of 3:1 were assayed by AAS for the elemental composition especially for $\mathrm{Zn}$ (1.29ppm) and $\mathrm{Cr}$ (below detectable levels). An appropriate amount of Zinc chloride $\left(\mathrm{ZnCl}_{2}\right)$ and potassium dichromate $\left(\mathrm{K}_{2} \mathrm{Cr}_{2} \mathrm{O}_{7}\right)$ solutions were added in aqueous solutions to attain required concentration of $350 \mathrm{ppm} \mathrm{Zn}$ and $8 \mathrm{ppm} \mathrm{Cr}$ were mixed with the soil to make up the experimental beds. The experiments were set up at laboratory conditions; three sets of ten replicates, a total of thirty experimental beds containing 350ppm Zn, 8ppm $\mathrm{Cr}$ and distilled water to control beds were used. Experimental beds having $30 \%$ of moisture were arranged in plastic culture boxes, covered with a perforated lid for aeration and fine gauze to prevent escape of worms. Ten control beds were prepared with distilled water as mentioned above. Ten earthworms were introduced to each box after voiding their gut contents and kept at $24 \pm 2^{\circ} \mathrm{C} 22$. Six worms were randomly selected from different replicates from each metal exposure for further assay.

\section{Feeding rate evaluation}

The methodology used by Sunitha Seenappa ${ }^{23}$ for the assessment of growth and bioenergetics parameters in Eudrilus eugeniae was adapted in this study to evaluate the feeding rate of earthworms. The experimental beds were prepared with a thin layer of soil, (as it allows air to passively diffuse into the material) and dry cow dung flakes of known weight, which was soaked in 350ppm of $\mathrm{ZnCl}_{2}$ solution and 8ppm of $\mathrm{K}_{2} \mathrm{Cr}_{2} \mathrm{O}_{7}$ solution were provided to the worms separately. The left out flakes were picked carefully by separating them from worm castings which are easily recognizable as they cast on the surface in the form of pyramids of finely divided soil ${ }^{24}$ and weighed. The amount of feed consumed was measured by weighing the left out food on 7, 14, 21 and 28days of exposure.

Rate of food consumed was calculated as =

$$
\frac{\text { Amount of food consumed }}{\text { Amount of food provided }} \times 100
$$




\section{Body weight changes}

Changes occurred in body weight indices were measured by removing ten individual worms from the substrate randomly from the replicates, from each treatment, washing them in distilled water and drying them on paper towels, and were weighed individually for the change in body weight. To minimize the interference of gut contents, the worms were weighed at a particular time in the mornings after observing the fresh casts, assuming the worms voided their gut contents.

$\%$ change in body weight is calculated as $=\frac{\text { Intitial body weight }}{\text { Final body weight }} \times 100$

\section{Measurement of reproductive rate}

To measure the reproductive rate, the cocoons in each culture box were counted at the end of $30^{\text {th }}$ day, and the number of hatched cocoons and the hatchlings in the substrate were counted.

Percent hatchability was calculated as $=$ $\frac{\text { Total cocoons hatched }}{\text { Total cocoons laid }} \times 100$

Reproductive rate $=$ cocoons produced $\times 100$ cocoons/adult/day.

\section{Data Analysis}

Data was analysed statistically using SPSS software (version 20.0). One-way ANOVA followed by post hoc Duncan multiple range test $(p<0.05)$ was used as applicable statistical tool for feeding rate evaluation and body weight changes and Dunnett's post hoc $(p<0.05)$ for comparing different soils. The results are presented as mean \pm standard error. Values in brackets refer to percentage change, '+' sign indicate increase and '-'sign indicate decrease over control. Percentage change was calculated as follows:

$\%$ Change $=\frac{\text { Control }- \text { Experimental }}{\text { Control }} \times 100$

\section{RESULTS}

\section{Soil analysis}

Physico-chemical properties of the soil samples are shown in table 1 and the data depict the mean values of $\mathrm{pH}$, conductivity, organic carbon, available phosphorous $\left(\mathrm{P}_{2} \mathrm{O}_{5}\right)$ and potassium $\left(\mathrm{K}_{2} \mathrm{O}_{5}\right)$.
Similarly the mean soil heavy metal concentration of the soils is given in table 2 . Soils irrigated with waste water were found to have varying concentrations of heavy metals, which were determined at sampling sites. Total heavy metal concentrations $(\mathrm{mg} / \mathrm{kg})$ in soils of $\mathrm{pH} 3.5$ to 7.1 from all sites ranged from 15.3 to $149 \mathrm{mg} / \mathrm{kg}$ for $\mathrm{Cu} ; 5.3$ to $15.84 \mathrm{mg} / \mathrm{kg}$ for $\mathrm{Zn} ; 28.1$ to $79.5 \mathrm{mg} / \mathrm{kg}$ for $\mathrm{Fe}$; $<0.1$ to $0.28 \mathrm{mg} / \mathrm{kg}$ for $\mathrm{Pb} ; 0.12$ to $0.225 \mathrm{mg} / \mathrm{kg}$ for $\mathrm{Cr} ; 0.05$ to $1.02 \mathrm{mg} / \mathrm{kg}$ for Ni; 0.7 to $7.0 \mathrm{mg} / \mathrm{kg}$ for $\mathrm{Mg}$ and 0.46 to $1.35 \mathrm{mg} / \mathrm{kg}$ for $\mathrm{Mn}$. Significant $(p<0.05)$ increase in metal concentrations of the sampled soils was evident compared to control soil.

\section{Distribution of earthworms}

The diversity of species of earthworms recorded in the studied areas viz., Eudrilus eugeniae, Lampito maurutii, Pontoscolex corethrurus, perionyx excavatus, Polypheretima elongata and Eisenia fetida, however species abundance varied among sampling sites, E.eugeniae and L.maurutii being the most dominant species followed by P.corethrurus, polypheretima elongata and Eisenia fetida. Identifying key characteristics of species and their distribution in the sampled areas is represented in table 3.

\section{Feed consumption}

The data shown in table 4 illustrate the rate of food consumption in earthworm Eudrilus eugeniae upon exposure to sublethal doses of $\mathrm{Zn}$ (350ppm) and $\mathrm{Cr}$ (8ppm). In E.eugeniea, a significant $(p<0.05)$ difference in the rate of food uptake was observed on $7^{\text {th }}$ day of $\mathrm{Zn}$ exposure whereas in $\mathrm{Cr}$ exposed group statistically significant change was evident on $7^{\text {th }}, 14^{\text {th }}$ and $21^{\text {st }}$ day of exposure. The percent change observed in food intake in Zn spiked soils were found to be $-37.09 \%,-2.97 \%,+16.90 \%,+12.45 \%$ and in $\mathrm{Cr}$ spiked soils the changes were $-39.51 \%$, $-29.55 \%,-36.10 \%$ and $+6.77 \%$ on $7^{\text {th }}, 14^{\text {th }}, 21^{\text {st }}$ and $28^{\text {th }} \mathrm{d}$ respectively. In species L.maurutii, a similar significant $(p<0.05)$ change in food uptake was seen on $7^{\text {th }}, 21^{\text {st }}$ and $28^{\text {th }} d$ of exposure while in Cr spiked soils significant difference was evident on $14^{\text {th }}, 21^{\text {st }}$ and $28^{\text {th }} \mathrm{d}$. The percent change observed in $\mathrm{Zn}$ exposed worms were found to be $+33.33 \%,+3.35 \%$, $+32.75 \%$ and $+14.15 \%$ and in $\mathrm{Cr}$ treated worms it $-14.03 \%,-27.51 \%,-34.49 \%$ and $-23.19 \%$ on $7^{\text {th }}$, $14^{\text {th }}, 21^{\text {st }}$ and $28^{\text {th }} \mathrm{d}$ respectively. In P.corethrurus, the percent change noticed in food uptake was found to be $-18.84 \%,+5.50 \%,+10.00 \%$ and $+22.78 \%$ and in 
Cr spiked soils it was $-37.68 \%,+0.91 \%,-17.77 \%$ and $-2.95 \%$ on $7^{\text {th }}, 14^{\text {th }}, 21^{\text {st }}$ and $28^{\text {th }}$ d respectively. However, in Zn spiked soils significant $(p<0.05)$ difference was evident on $21^{\text {st }}$ and $28^{\text {th }} d$ of exposure while in $\mathrm{Cr}$ spiked soil significant $(p<0.05)$ difference was evident on $7^{\text {th }} \mathrm{d}$ of toxic exposure.

\section{Body weight changes}

The data shown in table 5 indicate the changes observed in the body weight in E. eugeniae, $L$. maurutii and $P$. corethrurus upon exposure to sub lethal doses of $\mathrm{Zn}$ and $\mathrm{Cr}$ over a time interval of 28days. A significant increase was also evident in the body weight upon exposure to $\mathrm{Zn}$ and the observed values were found to be $+180.9 \%,+86.2 \%$, $+20.0 \%$, and $+21.1 \%$ in E. eugeniae, $+20.8 \%$, $+10.6 \%,-3.89 \%+6.25 \%$ in L.maurutii and $-12.12 \%$, $-17.46 \%,-26.0 \%, 21.71 \%$ in $P$. corethrurus on $7^{\text {th }}$, $14^{\text {th }}, 21^{\text {st }}$ and $28^{\text {th }}$ d respectively. While in Cr-spiked soils, a significant decrease in the body weight was evident, with a change of $-23.8 \%,-41.3 \%,-40.7 \%$, and $-27.1 \%$ in E. eugeniae; $-16.66 \%,-23.40 \%$, $-27.27 \%$, $-41.96 \%$ in L.maurutii; $-27.27 \%,-36.50 \%$, $-40.0 \%$ and $-54.60 \%$ in P. corethrurus on $7,14,21$ and $28 \mathrm{~d}$ respectively. Day wise effect of change in body weight of the worms were found significant using analysis of variance (one-way), post hoc Duncan $(p<0.05)$.

\section{Reproductive indices}

Reproductive indices recorded in terms of total cocoons, hatchability and reproductive potential of earthworm species studied is shown in table 6 . In E.eugeniae, the mean total cocoons produced in the control group was found to be $22.0 \pm 1.08$, while in treated group the total cocoons produced were found to be $30.50 \pm 2.65$ in $\mathrm{Zn}$ and $13.3 \pm 1.32$ in $\mathrm{Cr}$ treated soils. Likewise a significant difference was evident between total cocoons and hatching rate in both $\mathrm{Zn}$ and $\mathrm{Cr}$ exposed groups, wherein an increased $(+39.17 \%)$ rate of hatchlings was apparent in $\mathrm{Zn}$ spiked soils. Contrarily a decreased $(-77.83 \%)$ rate of hatchlings were evident in $\mathrm{Cr}$ exposed groups. Further, a significant increase in the rate of hatchability $(+7.85 \%)$ and reproductive rate $(+39.56 \%)$ was observed in $\mathrm{Zn}$ exposed group, while in $\mathrm{Cr}$ exposed groups a decreased rate of hatchability $(-39.65 \%)$ and reproductive rate $(-35.16)$ was evident.
In L. maurutii, there was no significant $(p<0.05)$ difference between total cocoons hatched in $\mathrm{Zn}$ spiked soils while significant difference was observed in $\mathrm{Cr}$ exposed groups. The mean total cocoons produced in the control group was $2.0 \pm 0.47$, while in treated groups the total cocoons produced were found to be $1.10 \pm 0.27$ in $\mathrm{Zn}$ and $0.6 \pm 0.22$ in $\mathrm{Cr}$ treated soils. Increased (+60.0\%) number of hatchlings in $\mathrm{Zn}$ spiked soils were observed though there was no difference in number of hatchlings in Cr spiked soils compared to control. Likewise, there was no significant $(p<0.05)$ difference in the total cocoons produced $(-35.71 \%)$, hatchability $(+2.86 \%)$ and reproductive rate $(-37.5 \%)$ in $\mathrm{Zn}$ spiked soils. Whereas a significant $(p<0.05)$ reduction in total cocoons $(-70.0 \%)$ formed and reproductive rate $(-62.5 \%)$ was observed in $\mathrm{Cr}$ spiked soils, though there was an insignificant decrease in hatchability rate $(-57.14 \%)$.

In P.corethrurus, there was no significant $(p<0.05)$ difference seen in reproductive indices between control and metal spiked soils. The total cocoons formed were found to be $1.10 \pm 0.31$ in control and $1.2 \pm 0.38$ and $0.50 \pm 0.16$ in $\mathrm{Zn}$ ad $\mathrm{Cr}$ spiked soils respectively. The percent change observed in total cocoons hatched $(-20.0 \%$ in $\mathrm{Zn}$; $-50.0 \%$ in $\mathrm{Cr})$, hatchability rate $(-32.49 \%$ in $\mathrm{Zn} ;-24.99 \%)$ and reproductive rate $(+25.0 \%$ in $\mathrm{Zn} ;-50.0 \%$ in $\mathrm{Cr})$ in metal spiked soils were evident. Though there was no difference in total hatchlings formed in $\mathrm{Zn}$ spiked soils decreased $(-50.0 \%)$ number of hatchlings were observed in $\mathrm{Cr}$ spiked soils compared to control.

\section{DISCUSSION}

Earthworms have been used as model organisms to assess the potential ecological risk on soil ecosystems caused by pollutants ${ }^{25}$ and hence considered as primary organisms which play an important role in soil functionality. They are the major agents of the soil fauna biomass, providing soil aeration and drainage and act as primary decomposers of organic matter ${ }^{26}$ whose functions may be suppressed due to pollutants. Earthworm responses to continuous heavy metal pollution provides vital information for monitoring environmental risks based on their ecological significance and duration of exposure. Each soil 
is specific in terms of pollution monitoring as the quantity of heavy metals introduced and its behaviour is associated with soil properties ${ }^{27}$. Findings of Rattan ${ }^{28}$ advocates that soil is nutrient rich and the presence of heavy metals in high concentrations implies its persistence, affects the productivity in long-term. Heavy metals are released into the soil by decomposition process but due to their limited solubility and restricted plant uptake, it gets accumulated in top layers of soil and become integrated part of soil environment by binding to specific adsorption sites of inorganic or organic particles ${ }^{29}$. Living organisms require trace amount of heavy metals including $\mathrm{Fe}, \mathrm{Co}, \mathrm{Cu}, \mathrm{Mg}$, $\mathrm{Va}$ and $\mathrm{Zn}$ for regulation of normal health. Excess amount of heavy metals can deteriorate normal physiology of an animal. Other heavy metal such as $\mathrm{Cd}, \mathrm{Pb}$, and $\mathrm{Hg}$ do not serve beneficial effects and their accumulation over the time in animals can cause ill effects or pathology. In this study, the samples collected from different industrial pockets of Bangalore (sites: A, G, L, T) were analysed for their elemental composition and it is evident from the results that agricultural lands adjacent to industrial pockets possess the elements like $\mathrm{Zn}$ (5.3 to $15.84 \mathrm{mg} / \mathrm{kg}$ ), Cu (15.3 to $149 \mathrm{mg} / \mathrm{kg}$ ), Mg (0.7 to $7.0 \mathrm{mg} / \mathrm{kg}), \mathrm{Fe}$ ( 28.1 to $79.5 \mathrm{mg} / \mathrm{kg}), \mathrm{Ni}(0.05$ to $1.02 \mathrm{mg} / \mathrm{kg}), \mathrm{Pb}(0.1$ to $0.28 \mathrm{mg} / \mathrm{kg}), \mathrm{Mn}(0.46$ to $1.35 \mathrm{mg} / \mathrm{kg})$ and $\operatorname{TCr}(0.12$ to $0.225 \mathrm{mg} / \mathrm{kg})$. Though the concentrations of metals analysed from the sampled sites were below the prescribed levels, the confined/restricted distribution could probably due to synergism between contaminant interactions. Studies have shown that distribution of earthworm species depends on the soil qualities such as soil moisture, texture, depth, $\mathrm{pH}$, and organic matter content.

Table 1: Physico-chemical characteristics of soils collected from industrial pockets of Bangalore.(Site C: control; A: Attibele, G: Gudimaavu; L: Lingapura; T: Thagachaguppe)

\begin{tabular}{cccccc}
\hline & pH & EC & $\begin{array}{c}\text { Organic } \\
\text { Carbon }\end{array}$ & $\begin{array}{c}\text { Available } \\
\mathbf{P}_{\mathbf{2}} \mathbf{O}_{5}\end{array}$ & $\begin{array}{c}\text { Available } \\
\mathbf{K}_{\mathbf{2}} \mathbf{O}_{5}\end{array}$ \\
\hline Site: $\mathrm{C}$ & $7.0 \pm 0.04$ & $0.625 \pm 0.004$ & $0.16 \pm 0.01$ & $20.25 \pm 0.62$ & $212.0 \pm 2.9$ \\
Site: $A$ & $4.1 \pm 0.23^{*}$ & $0.612 \pm 0.09^{*}$ & $1.00 \pm 0.24^{*}$ & $51.0 \pm 13.20$ & $290.5 \pm 32.4^{*}$ \\
Site: $G$ & $6.4 \pm 0.21$ & $0.167 \pm 0.03$ & $0.3375 \pm 0.65$ & $6.00 \pm 1.15$ & $109.0 \pm 13.2$ \\
Site: $L$ & $6.95 \pm 0.34$ & $0.137 \pm 0.036$ & $0.412 \pm 0.039$ & $76.0 \pm 15.5^{\star}$ & $226.5 \pm 5.5$ \\
Site: $T$ & $6.42 \pm 0.29$ & $0.212 \pm 0.031$ & $0.550 \pm 0.02$ & $34.45 \pm 6.6$ & $219.5 \pm 31.3$ \\
\hline
\end{tabular}

Values are represented as mean \pm Std error of three replicates $(n=3)$. '*' represents statistically significant $(p<0.05)$ difference compared to control (site: $C)$ using one-way ANOVA SPSS (version 20.0) Dunett's post hoc test

Table 2: Micronutrients and Heavy metal concentrations in soils from industrial pockets of Bangalore. (Site C: control; A: Attibele, G: Gudimaavu; L: Lingapura; T: Thagachaguppe)

\begin{tabular}{lcccccccc}
\hline & $\begin{array}{c}\mathrm{Zn} \\
(\mathbf{m g} / \mathbf{k g})\end{array}$ & $\begin{array}{c}\mathrm{Cu} \\
(\mathbf{m g} / \mathbf{k g})\end{array}$ & $\begin{array}{c}\mathrm{Mg} \\
(\mathbf{m g} / \mathbf{k g})\end{array}$ & $\begin{array}{c}\mathrm{Fe} \\
(\mathbf{m g} / \mathbf{k g})\end{array}$ & $\begin{array}{c}\mathrm{Ni} \\
(\mathbf{m g} / \mathbf{k g})\end{array}$ & $\begin{array}{c}\mathrm{Pb} \\
(\mathbf{m g} / \mathbf{k g})\end{array}$ & $\begin{array}{c}\mathrm{Mn} \\
(\mathbf{m g} / \mathbf{k g})\end{array}$ & $\begin{array}{c}\mathrm{TCr} \\
(\mathbf{m g} / \mathbf{k g})\end{array}$ \\
\hline Site: C & $9.8 \pm 0.14$ & $3.05 \pm 0.06$ & $33.27 \pm 0.22$ & $48.5 \pm 1.04$ & $0.12 \pm 0.0$ & $0.051 \pm 0.02$ & $2.42 \pm 0.08$ & $0.05 \pm 0.02$ \\
Site: A & $15.33 \pm 0.32^{*}$ & $1.1 \pm 0.17^{*}$ & $23.27 \pm 3.7$ & $98.12 \pm 3.8^{*}$ & $0.01 \pm 0.0^{*}$ & $0.0 \pm 0.0$ & $0.91 \pm 0.17^{*}$ & $0.19 \pm 0.02^{*}$ \\
Site: G & $6.72 \pm 1.8$ & $3.5 \pm 0.53$ & $72.65 \pm 25.4$ & $42.42 \pm 6.99$ & $0.15 \pm 0.02$ & $0.0 \pm 0.0$ & $1.77 \pm 0.20^{*}$ & $0.30 \pm 0.00^{*}$ \\
Site: L & $6.43 \pm 0.65$ & $5.57 \pm 0.59^{*}$ & $48.6 \pm 1.06$ & $67.0 \pm 5.3^{*}$ & $0.065 \pm 0.0$ & $0.3 \pm 0.09^{*}$ & $0.53 \pm 0.10^{*}$ & $0.23 \pm 0.03^{*}$ \\
Site: $T$ & $11.9 \pm 0.22$ & $6.82 \pm 0.14^{*}$ & $49.55 \pm 0.45$ & $64.0 \pm 2.71$ & $0.91 \pm 0.03^{*}$ & $0.22 \pm 0.01^{*}$ & $0.52 \pm 0.02^{*}$ & $0.11 \pm 0.004$
\end{tabular}

Values are represented as mean \pm Std error of three replicates $(n=3){ }^{\text {(*)' }}$ represents statistically significant $(p<0.05)$ difference compared to control (site: C) using one-way ANOVA SPSS (version 20.0) Dunett's post hoc test. 


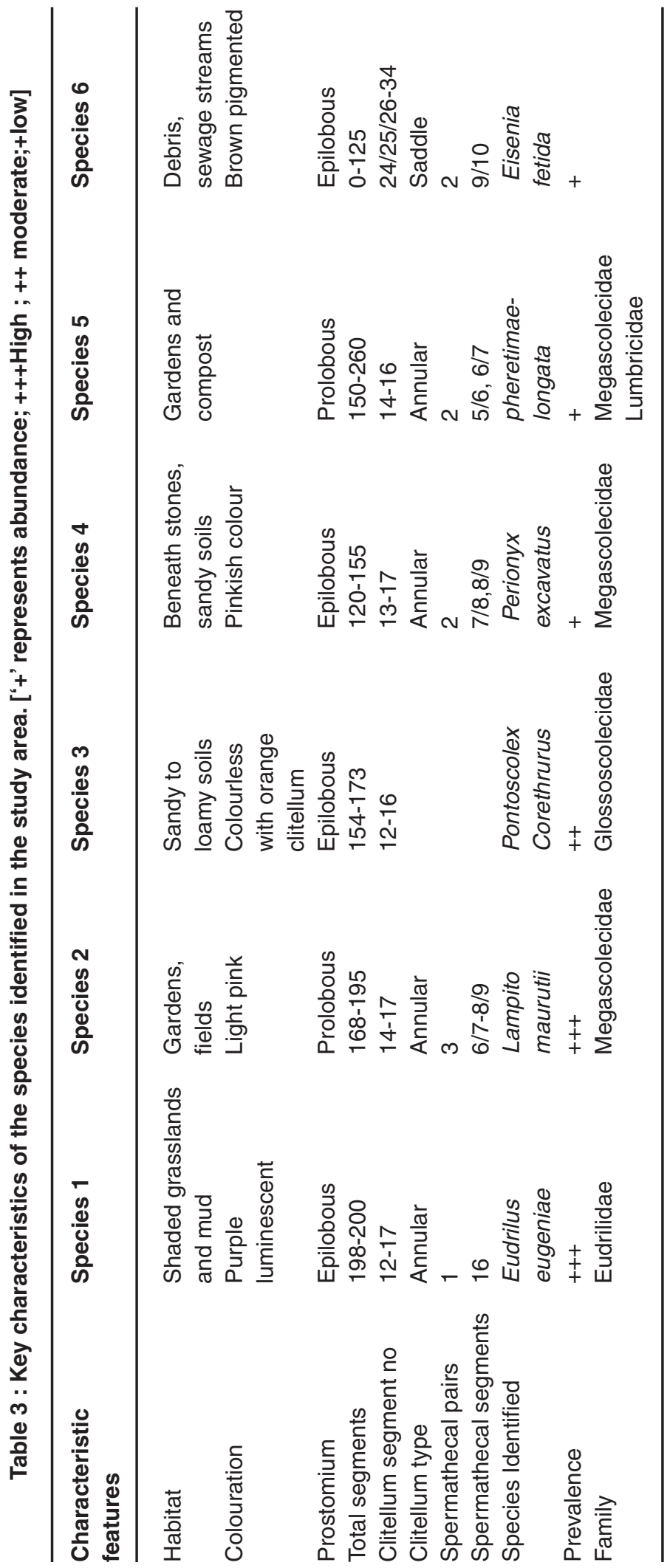


Table 4: Effect of sub lethal doses of Zinc (350ppm) and Chromium (8ppm) on average ingestion rate in Eudrilus eugeniae, Lampito maurutii and Pontoscolex corethrurus. Feed consumption (g consumed/worm/week)

\begin{tabular}{|c|c|c|c|c|c|}
\hline Species & Groups & 7day & 14day & 21day & 28day \\
\hline \multirow[t]{3}{*}{ E. eugeniae } & Control & $1.24 \pm 0.15^{\mathrm{a}}$ & $2.03 \pm 0.16^{a}$ & $3.49 \pm 0.41^{\mathrm{a}}$ & $5.46 \pm 0.73^{a}$ \\
\hline & Zinc & $\begin{array}{c}0.78 \pm 0.03^{b} \\
(-37.09)\end{array}$ & $\begin{array}{c}1.97 \pm 0.00^{\mathrm{a}} \\
(-2.97)\end{array}$ & $\begin{array}{c}4.08 \pm 0.17^{\mathrm{a}} \\
(+16.90)\end{array}$ & $\begin{array}{c}6.14 \pm 0.20^{\mathrm{a}} \\
(+12.45)\end{array}$ \\
\hline & Chromium & $\begin{array}{c}0.75 \pm 0.07^{b} \\
(-39.51)\end{array}$ & $\begin{array}{c}1.43 \pm 0.10^{\mathrm{b}} \\
(-29.55)\end{array}$ & $\begin{array}{c}2.23 \pm 0.23^{b} \\
(-36.10)\end{array}$ & $\begin{array}{c}5.83 \pm 1.95^{\mathrm{a}} \\
(+6.77)\end{array}$ \\
\hline \multirow[t]{3}{*}{ L. maurutii } & Control & $0.57 \pm 0.05^{\mathrm{a}}$ & $1.49 \pm 0.11^{\mathrm{a}}$ & $2.29 \pm 0.09^{\mathrm{a}}$ & $3.32 \pm 0.07^{a}$ \\
\hline & Zinc & $\begin{array}{c}0.76 \pm 0.03^{b} \\
(+33.33)\end{array}$ & $\begin{array}{c}1.54 \pm 0.09^{\mathrm{a}} \\
(+3.35)\end{array}$ & $\begin{array}{c}3.04 \pm 0.12^{\mathrm{c}} \\
(+32.75)\end{array}$ & $\begin{array}{c}3.79 \pm 0.18^{b} \\
(+14.15)\end{array}$ \\
\hline & chromium & $\begin{array}{c}0.49 \pm 0.06^{a} \\
(-14.03)\end{array}$ & $\begin{array}{c}1.08 \pm 0.08^{b} \\
(-27.51)\end{array}$ & $\begin{array}{c}1.50 \pm 0.10^{\mathrm{b}} \\
(-34.49)\end{array}$ & $\begin{array}{c}2.55 \pm 0.12^{\mathrm{c}} \\
(-23.19)\end{array}$ \\
\hline \multirow{3}{*}{ P. corethrurus } & Control & $0.69 \pm 0.06^{a}$ & $1.09 \pm 0.06^{a}$ & $1.80 \pm 0.07^{a}$ & $2.37 \pm 0.13^{a}$ \\
\hline & Zinc & $\begin{array}{c}0.56 \pm 0.07^{\mathrm{ab}} \\
(-18.84)\end{array}$ & $\begin{array}{c}1.15 \pm 0.09^{a} \\
(+5.50)\end{array}$ & $\begin{array}{c}1.98 \pm 0.17^{b} \\
(+10.00)\end{array}$ & $\begin{array}{c}2.91 \pm 0.14^{b} \\
(+22.78)\end{array}$ \\
\hline & chromium & $\begin{array}{c}0.43 \pm 0.06^{\mathrm{b}} \\
(-37.68)\end{array}$ & $\begin{array}{c}1.10 \pm 0.08^{a} \\
(+0.91)\end{array}$ & $\begin{array}{c}1.48 \pm 0.08^{a} \\
(-17.77)\end{array}$ & $\begin{array}{c}2.30 \pm 0.10^{\mathrm{a}} \\
(-2.95)\end{array}$ \\
\hline
\end{tabular}

Values are Mean \pm SE of 10 worms. Mean values with different superscript letters $(a, b, c)$ each column are statistically significant $(\mathrm{P}<0.05)$ as determined by DMRT.

Table 5: Body weight changes in Eudrilus eugeniae, Lampito maurutii and Pontoscolex corethrurus upon exposure to sub lethal doses of Zinc (350ppm) and Chromium (8ppm)

\begin{tabular}{|c|c|c|c|c|c|}
\hline Species & Groups & 7day & 14day & 21day & 28day \\
\hline \multirow[t]{3}{*}{ E. eugeniae } & Control & $0.021 \pm 0.006^{a}$ & $0.058 \pm 0.008^{a}$ & $0.130 \pm 0.012^{a}$ & $0.217 \pm 0.017^{a}$ \\
\hline & Zinc & $\begin{array}{c}0.059 \pm 0.007^{\mathrm{b}} \\
(+180.95)\end{array}$ & $\begin{array}{c}0.108 \pm 0.013^{b} \\
(+86.20)\end{array}$ & $\begin{array}{c}0.156 \pm 0.018^{a} \\
(+20.00)\end{array}$ & $\begin{array}{c}0.263 \pm 0.025^{\mathrm{a}} \\
\quad(+21.19)\end{array}$ \\
\hline & Chromium & $\begin{array}{c}0.016 \pm 0.003^{a} \\
(-23.80)\end{array}$ & $\begin{array}{c}0.034 \pm 0.004^{a} \\
(-41.37)\end{array}$ & $\begin{array}{c}0.077 \pm 0.009^{b} \\
(-40.76)\end{array}$ & $\begin{array}{c}0.158 \pm 0.012^{b} \\
(-27.18)\end{array}$ \\
\hline \multirow[t]{3}{*}{ L. maurutii } & Control & $0.024 \pm 0.002^{a}$ & $0.047 \pm 0.003^{a}$ & $0.077 \pm 0.004^{a}$ & $0.112 \pm 0.002^{\mathrm{a}}$ \\
\hline & Zinc & $\begin{array}{c}0.03 \pm 0.00^{\circ} \\
(+25.0)\end{array}$ & $\begin{array}{c}0.05 \pm 0.00^{\mathrm{a}} \\
(+6.38)\end{array}$ & $\begin{array}{c}0.074 \pm 0.003^{a} \\
(-3.89)\end{array}$ & $\begin{array}{c}0.119 \pm 0.005^{\mathrm{a}} \\
\quad(+6.25)\end{array}$ \\
\hline & chromium & $\begin{array}{c}0.02 \pm 0.00^{\mathrm{b}} \\
(-16.66)\end{array}$ & $\begin{array}{c}0.03 \pm 0.00^{\mathrm{b}} \\
(-36.17)\end{array}$ & $\begin{array}{c}0.056 \pm 0.008^{b} \\
(-27.27)\end{array}$ & $\begin{array}{c}0.065 \pm 0.003^{b} \\
(-41.96)\end{array}$ \\
\hline \multirow[t]{3}{*}{ P. corethrurus } & Control & $0.033 \pm 0.004^{a}$ & $0.063 \pm 0.004^{a}$ & $0.1 \pm 0.011^{\mathrm{a}}$ & $0.152 \pm 0.020^{\mathrm{a}}$ \\
\hline & Zinc & $\begin{array}{c}0.029 \pm 0.002^{a} \\
(-12.12)\end{array}$ & $\begin{array}{c}0.052 \pm 0.003^{b} \\
(-17.46)\end{array}$ & $\begin{array}{c}0.074 \pm 0.003^{b} \\
(-26.0)\end{array}$ & $\begin{array}{c}0.119 \pm 0.005^{a} \\
\quad(-21.71)\end{array}$ \\
\hline & chromium & $\begin{array}{c}0.024 \pm 0.001^{\mathrm{a}} \\
(-27.27)\end{array}$ & $\begin{array}{c}0.04 \pm 0.003^{c} \\
(-36.51)\end{array}$ & $\begin{array}{c}0.06 \pm 0.003^{b} \\
(-40.0)\end{array}$ & $\begin{array}{c}0.069 \pm 0.003^{\mathrm{b}} \\
(-54.61)\end{array}$ \\
\hline
\end{tabular}

Values are Mean \pm SE of 10 worms. Mean values with different superscript letters $(a, b, c)$ each column are statistically significant $(P<0.05)$ as determined by DMRT. 
Their density and biomass is chiefly monitored by food supply and quality and quantity of organic inputs returned to the soil ${ }^{30}$. Studies of Langdon et al. ${ }^{31}$ reported that laboratory metal spiked soils are more toxic than the field conditions of the same concentrations. Kale and Krishnamoorthy ${ }^{10}$ reported that the distribution and abundance of earthworms depends on the adaptability of the particular species to soil strata, more the adaptability higher will be the abundance. In this study E.eugeniae and $L$. maurutii were found in more number compared to other species may be due to build up of organic matter on surface layers. Prevalence of species also depends on the feeding rate as it is an important physiological process for energy requirement. In $\mathrm{Cr}$ exposed worms, decreased food intake could be a strategy of earthworms to avoid poisoning due to heavy metals and organic chemicals for its natural existence ${ }^{32}$. Furthermore, decreased body weight observed in $\mathrm{Cr}$ spiked soils may be attributed to the altered food intake and increased assimilation as casts. Maboeta et al. ${ }^{33}$ observed suppressed growth rate on exposure to low levels of lead in E.eugeniea, attributing the change to suppressed physiological response due to lead accumulation in the body of earthworms studied, explaining species sensitivity to metals. Likewise, Cesar et al. ${ }^{34}$ observed no inhibition of the feeding activity in collembolans, when subjected to the dredged sediment with low metal contamination.

Studies of Fleuren et al. ${ }^{35}$ showed that in contaminated soils the worms reduced their feeding rate, lowering the pollutant intake and found no difference in the amount of food consumed by juveniles and adult worms except for the gut retention time which was more in the juveniles of Eisenia andrei. The limited distribution of earthworms observed in the present study could also be due to ingestion of contaminated soils which might have affected the juveniles and hence decreased dispersion. Changes evident in reproductive indices could have influenced by the spiked metal as well as physical factors where cultures were maintained at

Table 6: Heavy metal ( $\mathrm{Zn} \mathrm{350ppm)} \mathrm{and} \mathrm{(Cr} \mathrm{8ppm)} \mathrm{induced} \mathrm{alterations} \mathrm{in} \mathrm{reproductive} \mathrm{indices} \mathrm{of}$ earthworm Eudrilus eugeniae, Lampito maurutii and Pontoscolex corethrurus

\begin{tabular}{|c|c|c|c|c|c|c|}
\hline Species & Groups & $\begin{array}{c}\text { Total } \\
\text { cocoons }\end{array}$ & $\begin{array}{c}\text { Total } \\
\text { hatched } \\
\text { Cocoons }\end{array}$ & $\begin{array}{c}\text { Total } \\
\text { hatchlings }\end{array}$ & $\begin{array}{l}\text { Hatchability } \\
\text { rate }\end{array}$ & $\begin{array}{c}\text { Reproductive } \\
\text { rate(cocoons/ } \\
\text { adult/day) }\end{array}$ \\
\hline \multirow[t]{3}{*}{ E. eugeniae } & Control & $22.0 \pm 1.08^{a}$ & $17.0 \pm 1.02^{\mathrm{a}}$ & $19.4 \pm 1.24^{a}$ & $77.16 \pm 2.11^{\mathrm{a}}$ & $0.091 \pm 0.00^{\mathrm{a}}$ \\
\hline & Zinc & $\begin{array}{c}30.50 \pm 2.65^{c} \\
(+38.63)\end{array}$ & $\begin{array}{c}25.6 \pm 2.60^{c} \\
(+50.58)\end{array}$ & $\begin{array}{c}27.0 \pm 2.68^{c} \\
(+39.17)\end{array}$ & $\begin{array}{c}83.22 \pm 1.93^{a} \\
\quad(+7.85)\end{array}$ & $\begin{array}{c}0.127 \pm 0.01^{\mathrm{b}} \\
(+39.56)\end{array}$ \\
\hline & Chromium & $\begin{array}{c}13.3 \pm 1.32^{b} \\
(-39.54)\end{array}$ & $\begin{array}{c}6.3 \pm 0.78^{b} \\
(-62.94)\end{array}$ & $\begin{array}{c}4.3 \pm 0.66^{\mathrm{b}} \\
(-77.83)\end{array}$ & $\begin{array}{c}46.56 \pm 3.10^{b} \\
(-39.65)\end{array}$ & $\begin{array}{c}0.059 \pm 0.005^{c} \\
(-35.16)\end{array}$ \\
\hline \multirow[t]{3}{*}{ L. maurutii } & Control & $2.0 \pm 0.47^{a}$ & $1.40 \pm 0.33^{a}$ & $0.50 \pm 0.2^{a}$ & $58.33 \pm 11.11^{a}$ & $0.008 \pm 0.0^{a}$ \\
\hline & Zinc & $\begin{array}{c}1.10 \pm 0.27^{\mathrm{ab}} \\
(-45.0)\end{array}$ & $\begin{array}{c}0.90 \pm 0.23^{\mathrm{ab}} \\
(-35.71)\end{array}$ & $\begin{array}{c}0.80 \pm 0.2^{a} \\
(+60.0)\end{array}$ & $\begin{array}{c}60.0 \pm 14.50^{\mathrm{a}} \\
(+2.86)\end{array}$ & $\begin{array}{c}0.005 \pm 0.0^{\mathrm{ab}} \\
(-37.5)\end{array}$ \\
\hline & Chromium & $\begin{array}{c}0.60 \pm 0.22 \text { b } \\
(-70.0)\end{array}$ & $\begin{array}{c}0.30 \pm 0.15^{b} \\
(-78.5)\end{array}$ & $\begin{array}{c}0.50 \pm 0.2^{a} \\
(0)\end{array}$ & $\begin{array}{c}25.0 \pm 13.43^{a} \\
(-57.14)\end{array}$ & $\begin{array}{c}0.003 \pm 0.0^{\mathrm{b}} \\
(-62.5)\end{array}$ \\
\hline \multirow[t]{3}{*}{ P. corethrurus } & Control & $1.10 \pm 0.31^{\mathrm{a}}$ & $1.0 \pm 0.25^{\mathrm{a}}$ & $0.60 \pm 0.22^{a}$ & $66.66 \pm 14.9^{a}$ & $0.004 \pm 0.0^{a}$ \\
\hline & Zinc & $\begin{array}{c}1.2 \pm 0.38^{\mathrm{a}} \\
(+9.0)\end{array}$ & $\begin{array}{c}0.80 \pm 0.24^{a} \\
(-20.0)\end{array}$ & $\begin{array}{c}0.60 \pm 0.16^{a} \\
(0)\end{array}$ & $\begin{array}{c}45.0 \pm 14.0^{\mathrm{a}} \\
(-32.49)\end{array}$ & $\begin{array}{c}0.005 \pm 0.0^{\mathrm{a}} \\
(+25.0)\end{array}$ \\
\hline & Chromium & $\begin{array}{c}0.50 \pm 0.16^{a} \\
(-54.54)\end{array}$ & $\begin{array}{c}0.50 \pm 0.16^{a} \\
(-50.0)\end{array}$ & $\begin{array}{c}0.30 \pm 0.15^{a} \\
(-50.0)\end{array}$ & $\begin{array}{c}50.0 \pm 16.6^{a} \\
(-24.99)\end{array}$ & $\begin{array}{c}0.002 \pm 0.0^{a} \\
(-50.0)\end{array}$ \\
\hline
\end{tabular}

Values are Mean \pm SE of 10 replicates (Each replicate containing 4 adult worms). Values in parenthesis indicate percentage change '+' indicates increase and '-'indicates decrease over control. Mean values with different superscript letters $(a, b, c)$ are statistically significant $(P<0.05)$ column wise as determined by one way ANOVA post hoc Duncan test. 
$25 \pm 2^{\circ} \mathrm{C}$. Several authors reported the influence of temperature on cocoon formation, hatchability and development time of cocoons. Cocoon development time for temperate epigeic worms Eisenia fetida (3273days), Dendrobaena veneta (40-126days), and for tropical epigeic worm E.eugeniea (13-27days) and Perionyx excavates (16-21days) was reported by $\mathrm{Edwards}^{36}$. Likewise, rare emergence of two juveniles from cocoons in L.maurutii was reported by Dash and Senapathi ${ }^{37}$. They also reported prolonged incubation period in L.maurutii is due to delayed development of hatchlings per cocoon due to limited availability of resources to all embryos in a cocoon. Even though, P. corethrurus is a continuous breeder with high fecundity which is an adaptive feature of peregrine worms and $L$. maurutii the widely distributed native species, are semi-continuous breeders ${ }^{38}$, in the study reduced reproductive rate was evident in both the species which may be due to the prevailing physical factors. Olive and Clark ${ }^{39}$ reported decreased neurosecretory activity as a result of shift in optimal temperature which was shown to affect cocoon production. Senapati and $\mathrm{Sahu}^{40}$ observed varying incubation period in temperate worms (3-30weeks) and tropical worms (1 to 8 weeks).

Greater cocoon formation rate with increased hatching success in epigeics E.eugeniae was due to high mortality risk in the environment and is probably an adaptive strategy to equip them to sustain severe climatic changes ${ }^{41}$. Lee ${ }^{42}$ reported that increased cocoon production is proportional to high risk of mortality in initial life stages. Cocoon formation and its development time vary from species to species and are dependent on species age, population density and climatic factors like temperature, moisture and energy content of the food. Anthropogenic activities leads to increase metal concentrations of toxic metals in surface soils resulting in decreased earthworm density ${ }^{43}$, and its extinction caused by metal overload is directly related to soil compaction and inconsistent litter build up which is critical in evaluating soil quality ${ }^{44}$.

In brief, this study reports the occurrence of six species of earthworms viz., Eudrilus eugeniae, Lampito maurutii, Pontoscolex corethrurus, Megascolex konkanensis, Polypheretima elongata and Perioynx excavates in selected areas which were minimal than the earlier record, exhibiting confined dispersion pattern of earthworms. The poor diversity of earthworms may be due to use of sewage effluents for irrigation practises and dominance of industries in agricultural zone which has influenced the soil metal concentrations causing impact on earthworms by altering their feeding, body mass changes and reproductive indices, in turn affecting its distribution. Hence monitoring pollution through soil characterisation reflects soil status and resultant species richness.

\section{ACKNOWLEDGEMENT}

This study was supported by University Grants Commission, SWRO, Bangalore in the form Teacher fellowship to Latha V. The authors would like to thank Prof Radha Kale, Research Director, Mount Carmel College, Bangalore for her expert suggestions.

\section{REFERENCES}

1. Pižl, V. and Josens, G. Earthworm communities along a gradient of urbanization. Environmental pollution, 90(1): 7-14 (1995)

2. Lavelle, P., and Spain, A.V. In: Soil ecology In Kluwer academic puSpringer Science \& Business Media (2001)

3. Weeks, J. M., Spurgeon, D. J., Svendsen, C., Hankard, P. K., Kammenga, J. E., Dallinger, R. Scott-Fordsmand, J. Critical analysis of soil invertebrate biomarkers: a field case study in Avonmouth, UK. Ecotoxicology, 13(8): 817822(2004)
4. Vranken, G., Tiré, C., and Heip, C. Effect of temperature and food on hexavalent chromium toxicity to the marine nematode Monhystera disjuncta. Marine Environmental Research, 27(2): 127-136(1989)

5. Julka, J., Paliwal, R., and Kathireswari, P. (2007). Biodiversity of Indian earthwormsan overview. Paper presented at the 2009. Proceedings of Indo-US workshop on Vermitechnology in human welfare, Coimbatore, India.

6. Dhiman, N., and Battish, S. Earthworms from 
Northern Indian states with Ocnerodrilus occidentalis, Eisen, 1878, as a new report from Punjab. Zoo's Print Journal, 21(1): 21352137(2006)

7. Bhattacharjee, G., and Chaudhuri, P. Cocoon production, morphology, hatching pattern and fecundity in seven tropical earthworm species-a laboratory-based investigation. Journal of biosciences, 27(3): 283-294(2002)

8. Karmegam, N., and Daniel, T. Abundance and population density of three species of earthworms (Annelida: Oligochaeta) in foothills of Sirumalai (Eastern Ghats), South India. Indian Journal of Environment and Ecoplanning, 3: 461-466(2000)

9. Padashetty, S. and Jadesh, M. An preliminary survey of earthworm species composition and distribution in the north Karnataka region, Gulbarga, Karnatak. International Letters of Natural Sciences, 22 (2014).

10. Kale, R. D., and Krishnamoorthy, R. Distribution and abundance of earthworms in Bangalore. Proceedings of the Indian Academy of Sciences-Section B, Animal Sciences, 87(3): 23-25(1978)

11. Walkley, A., \& Black, I. A. An examination of the Degtjareff method for determining soil organic matter, and a proposed modification of the chromic acid titration method. Soil science, 37(1): 29-38(1934)

12. Olsen, S. R. Estimation of available phosphorus in soils by extraction with sodium bicarbonate(1954)

13. Merwin, H., \& Peech, M. Exchangeability of soil potassium in the sand, silt and clay fractions as influenced by the nature of the complementary exchangeable cation. Paper presented at the Soil Sci Soc Am Proc(1951)

14. Baker, D. E., \& Suhr, N. H. Atomic absorption and flame emission spectrometry. Methods of soil analysis. Part 2. Chemical and microbiological properties (methods of soilan 2), 13-27(1982)

15. McLaughlin, M. J., Hamon, R., McLaren, R., Speir, T., \& Rogers, S. Review: A bioavailabilitybased rationale for controlling metal and metalloid contamination of agricultural land in Australia and New Zealand. Soil Research,
38(6): 1037-1086(2000)

16. Schalscha, E., Morales, M., Vergara, I., \& Chang, A. Chemical fractionation of heavy metals in wastewater-affected soils. Journal (Water Pollution Control Federation), 175180(1982)

17. Gaulhofer, J., Bianchi, V., 1991. Chromium. In Merian E, ed, Metals and Their Compounds in the Environment, Vol 1. VHC, Wein- heim, Germany, pp 853-878.

18. Wetterhahn, K. E., \& Hamilton, J. W. (1989). Molecular basis of hexavalent chromium carcinogenicity: effect on gene expression. Science of the Total Environment, 86(1): 113129.

19. Goyer, R. A., \& Clarkson, T. W. (1996). Toxic effects of metals. Casarett \& Doull's Toxicology. The Basic Science of Poisons, Fifth Edition, Klaassen, CD [Ed]. McGrawHill Health Professions Division, ISBN, 71054766.

20. Shanker, A. K., Cervantes, C., Loza-Tavera, H., \& Avudainayagam, S. Chromium toxicity in plants. Environment international, 31(5): 739-753(2005)

21. Finney, D. J. (1971). Probit Analysis: 3d Ed: Cambridge University Press.

22. Reinecke, A., \& Reinecke, S. The influence of heavy metals on the growth and reproduction of the compost worm Eisenia fetida(Oligochaeta). Pedobiologia, 40(5): 439448(1996)

23. Seenappa, S. N.(2011). Seasonal Effects on Growth and Bioenergetics of Eudrilus eugeniae (Kinb.) using Cane Sugar Pressmud (CSP) as Feed Substrate. Universal journal of enivironmental research and technology 1 : 467-475 (2011)

24. Edwards, C.A., Lofty, J.R., (1972). Biology of earthworms. Chapman and Hall, London 1-288

25. Ribera, D., Narbonne, J., Arnaud, C., \& Saint-Denis, M. Biochemical responses of the earthworm Eisenia fetida andrei exposed to contaminated artificial soil, effects of carbaryl. Soil biology and biochemistry, 33(7): 11231130(2001)

26. Edwards, C. A., \& Bohlen, P. J. Biology and ecology of earthworms (Vol. 3): Chapman and Hall publishers . New york. Springer Science 
\& Business Media(1996)

27. Marr, K., Fyles, H., \& Hendershot, W. Trace metals in Montreal urban soils and the leaves of Taraxacum officinale. Canadian journal of soil science, 79(2): 385-387(1999)

28. Rattan, R., Datta, S., Chhonkar, P., Suribabu, K., \& Singh, A. Long-term impact of irrigation with sewage effluents on heavy metal content in soils, crops and groundwater-a case study. Agriculture, Ecosystems \& Environment, 109(3): 310-322(2005)

29. Sauve, S., Hendershot, W., \& Allen, H. E. Solidsolution partitioning of metals in contaminated soils: dependence on $\mathrm{pH}$, total metal burden, and organic matter. Environmental Science \& Technology, 34(7): 1125-1131(2000)

30. Curry, J. P., \& Schmidt, O. The feeding ecology of earthworms-a review. Pedobiologia, 50(6), 463-477(2007)

31. Langdon, C. J., Piearce, T. G., Meharg, A. A., \& Semple, K. T.. Survival and behaviour of the earthworms Lumbricus rubellus and Dendrodrilus rubidus from arsenatecontaminated and non-contaminated sites. Soil biology and biochemistry, 33(9): 12391244(2001)

32. Wu, S., Wu, E., Qiu, L., Zhong, W., \& Chen, J. Effects of phenanthrene on the mortality, growth, and anti-oxidant system of earthworms (Eisenia fetida) under laboratory conditions. Chemosphere, 83(4): 429434(2011)

33. Maboeta, M., Reinecke, A., and Reinecke, S. The effects of low lead levels on the growth and reproduction of the African earthworm Eudrilus eugeniae (Oligochaeta). Biology and fertility of soils, 30(1-2): 113-116(1999)

34. Cesar, R., Natal-da-Luz, T., Silva, F., Bidone, E., Castilhos, Z., Polivanov, H., \& Sousa, J. P. Ecotoxicological assessment of a dredged sediment using bioassays with three species of soil invertebrates. Ecotoxicology, 24(2): 414-423 (2015)

35. Fleuren, R., Jager, D., Roeloefs, W., de Groot, A., Baerselman, R., \& Peijnenburg, W. Feeding activity of Eisenia andrei in two different field contaminated soils 47(5-6):670675(2003)

36. Edwards, C.A., Niederer, A., 1988. The production and processing of earthworms protein.In: Earthworms in waste and in Environment. SPB Academic Publishing, P.O.Box 97747, 2509 GC The Hague, The Netherlands, pp. 169-180.

37. Dash, M., Senapati, B., and Mishra, C. Nematode feeding by tropical earthworms. Oikos, 322-325(1980)

38. Fragoso, C., Kanyonyo, J., Moreno, A., Senapati, B. K., Blanchart, E., \& Rodriguez, C. A survey of tropical earthworms: taxonomy, biogeography and environmental plasticity;in Earthworm management in tropical agroecosystem(eds)P. Lavelle, L. Brussard, and P. Hendrix(London: CAB international) pp 1-26 (1999)

39. Olive, P. J. W., and Clark, R. B. Physiology of reproduction; in Physiology of annelids (ed.) P J Mill (London: Academic Press) pp 271-368(1978)

40. Senapati, B., \& Sahu, S. Population, biomass and secondary production in earthworms. Earthworm Resources and Vermiculture, 57-78(1993)

41. Sahu, S., \& Senapati, B. Selection pressure study on megascolecid earthworms from India. SUJ Sci. Tech.(Silver Jubilee Volume), 10: 46-52(1991)

42. Lee, K. E. Earthworms: their ecology and relationships with soils and land use: Academic Press Inc. (1985)

43. Gongalsky, K. B., Belorustseva, S. A., Kuznetsova, D. M., Matyukhin, A. V., Pelgunova, L. A., Savin, F. A., \& Shapovalov, A.S. Spatial avoidance of patches of polluted chernozem soils by soil invertebrates. Insect Science, 16(1): 99-105(2009)

44. Eijsackers, H., Beneke, P., Maboeta, M., Louw, J., \& Reinecke, A. The implications of copper fungicide usage in vineyards for earthworm activity and resulting sustainable soil quality. Ecotoxicology and Environmental Safety, 62(1): 99-111(2005) 